\title{
Loucos? Histórias de vida, significados do sofrimento psíquico e (des)institucionalização
}

\author{
Hudson Pires de Oliveira Santos Junior \\ Maria de Fátima de Araújo Silveira \\ Dulce Maria Rosa Gualda \\ Natalia Rejane Salim
}

\section{SciELO Books / SciELO Livros / SciELO Libros}

SILVEIRA, MFA., and SANTOS JUNIOR, HPOS., orgs. Residências terapêuticas: pesquisa e prática nos processos de desinstitucionalização [online]. Campina Grande: EDUEPB, 2011. 320 p. ISBN 97885-7879-063-9. Available from SciELO Books $<\underline{\text { http://books.scielo.org }>\text {. }}$

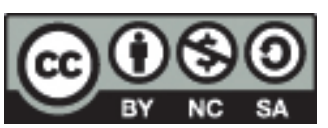

All the contents of this work, except where otherwise noted, is licensed under a Creative Commons Attribution-Non Commercial-ShareAlike 3.0 Unported.

Todo o conteúdo deste trabalho, exceto quando houver ressalva, é publicado sob a licença Creative Commons Atribuição Uso Não Comercial - Partilha nos Mesmos Termos 3.0 Não adaptada.

Todo el contenido de esta obra, excepto donde se indique lo contrario, está bajo licencia de la licencia Creative Commons Reconocimento-NoComercial-CompartirIgual 3.0 Unported. 


\section{Loucos? Histórias de vida, significados do sofrimento psíquico e (des)institucionalização}

Hudson Pires de Oliveira Santos Junior

Maria de Fátima de Araújo Silveira

Dulce Maria Rosa Gualda

Natalia Rejane Salim

\section{Iniciando o enredo da narrativa}

Diante da necessidade de aprofundar-nos no entendimento da relação cultura e processo saúde-doença, e aqui, particularmente, a doença mental, e dando continuidade às investigações conduzidas no âmbito das Residências Terapêuticas (SANTOS JUNIOR; SILVEIRA, 2009), surgiu a motivação de conduzir um estudo de cunho etnográfico com os egressos do hospital psiquiátrico, que foi descrito no capítulo anterior, deste livro.

Os internos que estavam saindo do hospital (ano de 2005), devido à intervenção do Ministério da Saúde, já eram considerados prováveis moradores dos Residenciais Terapêuticos a serem implantados na época, em Campina Grande. Porém, a articulação da equipe de intervenção com os familiares desses sujeitos atingiu sua proposta maior, que foi aceitação de alguns deles de volta ao seio familiar, garantindo um espaço de moradia e apoio. 
Entretanto, inquieta-nos a necessidade de responder a alguns questionamentos sobre o modo de inserção sociocultural desses sofredores psíquicos que passaram pelo processo de desinstitucionalização do Instituto Campinense de Neuropsiquiatria e Reabilitação Funcional (ICANERF), constituindo, então, o problema da presente proposta: Como está sendo a vida dos egressos do hospital psiquiátrico, após a desospitalização?

Para responder a tal questão, este estudo teve como objetivo: compreender qual o significado que os sofredores psíquicos atribuem a experiência de sair do hospital psiquiátrico, decorrente à intervenção do Ministério da Saúde, e como se dá o retorno destes atores sociais à comunidade. Buscou-se, dessa forma, apreender as categorias culturais relacionadas à problemática do adoecimento mental.

Para isso, o estudo ancora-se nos pressupostos da antropologia cultural e da etnografia como método de pesquisa qualitativa.

\section{Antropologia: fundamento para a caminhada}

Como afirma Minayo (1999), a doença é uma realidade construída e o doente um personagem social, o que indica a indiscutível importância da antropologia para a compreensão do processo saúde-doença, devido este ser composto por uma trama de fatos tanto clínicos quanto socioculturais, envolvendo, portanto, significação, interpretação e ações socialmente organizadas para promoverem a saúde e responderem à doença.

Considerando que a antropologiaéo estudo das culturas humanas em suas diversidades históricas e geográficas, Gualda e Bergamasco (2004) relatam que ela tem sido utilizada como uma perspectiva enriquecedora, na abordagem de temas relativos ao processo saúdedoença e dos universos sociais e culturais onde ocorrem. 
Destacam-se, então, dois enfoques teóricos na conceituação de cultura: o primeiro, comportamental, que se refere à observação do comportamento dos indivíduos de um determinado grupo social; e, o segundo, cognitivo, que busca conhecer e compreender as crenças, os valores e os conhecimentos desses sujeitos na abordagem do tema escolhido (GUALDA, 2002).

Nesse sentido e na tentativa de compreender o continuum saúde-doença mental em seus contextos socioculturais mais amplos, buscamos subsídios no referencial da antropologia cultural, pois sua utilização, quer envolva direta ou indiretamente o processo saúdedoença, pode constituir-se em uma perspectiva complementar e enriquecedora (GUALDA, 2002).

Contudo, as análises das Ciências Sociais, no campo da antropologia e sociologia, foram conduzidas por uma linha de relativização da doença mental. Pautando-se na revelação de que tanto a loucura quanto os modos de responder a ela emergem de determinados contextos sociais, ou seja, a loucura é um fenômeno sociocultural e possui as marcas da sociedade em que fora criada.

No século XVIII, entra no contexto o hospital psiquiátrico e a medicina, na figura do psiquiatra, que assume um papel de antiherói que, utilizando como pano de fundo o discurso terapêutico, exerce sua principal tarefa: a de controle social sobre a loucura.

O foco central é tirar das ruas as pessoas ditas loucas e levá-las para uma instituição manicomial, onde haja tratamento. Contudo, a eficácia desse sistema começa a ser questionada. As críticas apontavam para uma crise do sistema psiquiátrico, que além de não intervir na qualidade de saúde dos internos, era o produtor e mantenedor do adoecimento, responsável pelo alto índice de mortalidade e cronificação dessas pessoas, gerando inúmeras incapacidades sociais.

Em decorrência dessa realidade, cria-se um movimento internacional de Reforma Psiquiátrica, cujo objetivo é lutar pela desconstrução da assistência psiquiátrica hospitalar. O Brasil, em 
particular, orientou sua reforma psiquiátrica inspirando-se na experiência itálica de reversão dos hospitais psiquiátricos por dispositivos inseridos e articulados socialmente, com o intuito de alcançar a reinserção socioeconômico-cultural das pessoas em sofrimento mental e de re-estruturar as práticas de cuidados a elas despendidas.

Todavia, reduzir leitos e superar a condição cronificante de "moradores do hospital" a que muitos sofredores psíquicos são relegados implica a formação de alternativas de moradias para os futuros egressos, seja pelo suporte requerido para garantir sua permanência fora do hospital, seja pela dificuldade de reinserção familiar. Para isso, a atual política de saúde mental tem contado com o apoio integral dos Serviços Terapêuticos Substitutivos, em especial, as Residências Terapêuticas (RTs), instituídas pela Portaria 106/2000 do Ministério da Saúde.

\section{A etnografia deu significado às escolhas tomadas}

Dentre os métodos qualitativos existentes, este estudo adotou o etnográfico, a partir dos pressupostos da antropologia cultural interpretativa (GEERTZ, 1989). Segundo Gualda (2002), o elemento essencial da etnografia é buscar compreender o modo de vida da pessoa ou grupos na sua própria perspectiva. Ainda para a autora, a etnografia é um processo sistemático de observar, detalhar, descrever, documentar e analisar o estilo de vida da cultura de um determinado grupo de sujeitos.

O estudo foi realizado em Campina Grande, interior do estado da Paraíba, devido ao fato deste município está experimentando e implementando medidas para a desinstitucionalização de pessoas com internações psiquiátricas de longa permanência.

Com base na perspectiva teórica, decidimos trabalhar com as narrativas, pois é complementar para projetos que combinam 
histórias de vida e contextos sócio-históricos, sendo, portanto, adequadas para apreender os significados que os sofredores psíquicos atribuem a vivência com o transtorno mental.

\section{Para voltar no tempo é necessário um constante ir e vir}

Através da história de vida é possível emergir a linguagem própria de cada sujeito, que gera um discurso sócio-sentimental acerca do fenômeno que o envolve, que neste caso é o adoecimento mental. Em cada história de vida, existe um tom vital, que é a frase escolhida para servir de síntese da moral da narrativa. Eis os tons vitais:

Eu ia me casar e adoeci, foi por causa desse casamento, porque ele [noivo] me ligou dizendo que ia ter um filho... fiquei doidinha na hora, me disseram que era esquizofrenia simples. Eu ficava normal e não sei o que era que eu fazia. (Ana)

Quando eu era criança, desse tamanhinho assim, eu fui crescendo, crescendo, aí não colocaram roupa neu, aí eu fui ficando nervoso. Eu andava pelo mato, porque eu andava nu e tinha medo de gente, tipo índio. (Voni)

Meus irmãos começaram a me tratar como se eu fosse doida, perguntavam: "ta melhor?" Eu dizia: "melhor de que? Vocês são doidos e colocaram na cabeça que a doida sou eu. Não querem é que eu vá morar na casa de vocês e me apresentar como a mulher que não tem dinheiro". (Zoe)

Me disseram que eu tinha problema de cabeça... Quando eu ficava interno no hospital psiquiátrico, vixe Maria! Lá era ver uma cadeia, comida não prestava, era a mesma comida todo dia, eu lá passei muita fome. O tratamento era 
selvagem, que nem um bocado de burro tudo bravo, tinha remédio, tinha tudo, mas era doido com doido, era briga e mais briga. (José)

Ixe! Eu era a menina dos olhos de ouro de meu pai. Eu não podia ter uma febrezinha de nada que ele corria para um médico particular. Hoje bate uma decadência, tanto na estabilidade econômica como na estabilidade emocional. (Jucilene)

A partir das histórias de vida na íntegra, fizemos recortes que retratam as categorias culturais expressas:

\section{Naquela época era tudo diferente do que é visto hoje...}

Ao responderem a colocação do pesquisador "conte-me sobre sua história de vida", os colaboradores foram instigados à rememoração. Neste momento, eles se mostraram dispostos a relembrar de acontecimentos e de pessoas situadas nos diversos momentos de suas vidas. Como diz Santos (2000) voltar no tempo é um exercício que necessita de um constante ir e voltar, pois cada lembrança ancora-se em um momento do presente, pois “a lembrança é em larga medida uma reconstrução do passado com a ajuda de dados emprestados do presente".

Os colaboradores, quando constroem suas histórias de vida, fazem de forma bastante livre, sem se prenderem, na maior parte das vezes, a uma organização cronológica. Diante desse fato, a transcrição das entrevistas possibilitou uma leitura lógica e cronológica, quando possível, dos eventos narrados.

Eu sou natural de Souza-PB, eu vivia na fazenda quando ainda era criança, nessa época eu não fazia nada a não ser brincar com meu 
irmão 1. Aí, brincava muito, né? Corria, brincava nas mangueiras, nos açudes. (Zoe)

Eu sou de Santana do Cariri no Ceará, nasci no dia 11 de setembro de 1975, às 6 horas da manhã. Quando eu era criança, eu gostava de brincar um pouco de boneca, eu gostava muito de participar daquelas pessoas, daquelas meninas, daquelas crianças tudinho... naquela época, o regime era só brincadeira. (Jucilene)

Eu jogava bola, jogava pedra, fazia tudo, de criança, né? Jogava bola de vrido, bolinha de vrido, lascava cabeça de meninos que não era brincadeira, lascava com pedra... na brincadeira vale tudo. (José)

Pode-se observar que as narrativas trazem a origem do colaborador "sou de...", local onde foram vividos os "bons" momentos da infância, marcados por situações de brincadeiras, pois como traz a fala o "regime era só brincadeira", diferindo do contexto atual onde as crianças são encaminhadas para uma série de atividades diárias, como escola, natação, judô, informática e outras (seja a nível privado ou em Organizações Não Governamentais), cujo objetivo é tirar-lhes das ruas e oferecer uma suposta educação de qualidade, bem como proteger do perigo da violência urbana.

As narrativas trazem também as lembranças dos momentos na escola como um espaço de aprendizado, porém duas experiências nos chamam atenção, por se referirem aos colégios administrados por freiras.

Era bom no colégio que eu tive, Instituto Beneficente São José, no primário. Na década de 55 era muito diferente dessa década, eu gostava muito das quermesses que tinha no colégio, das freiras, eu estudei em colégio de freira. (Jucilene) 
Eu fui para as Damas (colégio administrado por freiras) pra estudar, né? Nas Damas eu era muito estudiosa, mas eu não tolerava lá, porque se você vai assistir aula só querem saber de filho de deputados e senadores, só dá cartaz a filhos de médicos, é essas coisas que eu nunca gostei. A mestra geral humilhava muito, pegava muito no pé com nossa roupa, nosso cabelo, sempre foi assim. Não tratava a gente muito bem, essas coisas machucam, né? Um erro só, puxava a campainha e todo mundo ficava de castigo, nessas horas tinha duas moças, filhas de um político famoso, com cara de sonsa, vivia agarrada na saia da freira, era essas diferenciações que eu já não aceitava. Aí, a gente cantava: "e o cordão do puxa saco cada vez aumenta mais", era uma turma perigosa a nossa! Naquela época era tudo muito diferente do que é visto hoje, né? (Zoe)

Novamente surge a referência em relação à diferença entre as épocas: "década de 55 era muito diferente dessa década", apontando mudanças no processo educativo, antes marcado por colégios religiosos, cujo rigor e a lei são o meio educativo. Tomando a análise das instituições totais no livro "Manicômios, prisões e conventos" (GOFFMAN, 2003), pode-se dizer que Zoe e Jucilene passaram, na infância, pela sua primeira experiência em uma instituição marcada pelas relações interpessoais verticais, mortificação da identidade pessoal e distanciamento dos espaços sociais.

É fato que a vida vai se passando e com ela vem o acúmulo de experiências:

Aí, quando eu me tornei adolescente eu gostava de praia, de brincar, de roupa nua, do jeito que as meninas passam aí na televisão. Eu era toda na moda, eu era danada, perigosa, 
namoradeira, namorava quando era nova. Meus pais não deixavam eu dar um prego numa barra de sabão, porque eles tinha condição regular, eles não deixavam. Quando eu era adolescente, gostava muito de passear no clube, no rio, nas festas boas, foi uma vida boa de mar de rosa. É tanto que hoje em dia não sei fazer nada, eu não sei lavar um copo que preste, se eu for lavar, minha filha vai e reclama, diz que eu faço mal feito, não faço bem feito. (Jucilene)

Em casa, eu varria a casa, eu arrumava, sabe? Adolescente começa com que idade? Eu trabalhava, passeava, gostava de passear, ali onde é hoje o camelódromo era o colegial, você não alcançou, viu? A gente ia passear à noite e ouvir música, todas as vezes ia, eu ia com minhas amigas, depois minhas amigas desapareceram, porque foram para outro lugar, aí eu saía com a minha irmã. Eu tenho 1 irmã e 1 irmão. Toda noite eu ia ao cinema, não pago, porque eu não podia pagar cinema toda noite, mas seu Zezinho do Capitólio (cinema) botava a mim e minha irmã para assistir o filme, depois das 8 horas, depois do jornal. Não me casei, cheguei bem pertinho de casar, só faltou mesmo ele vir. Ele vinha, mas eu pedi que suspendesse a viagem porque eu não podia deixar minha irmã e meu pai, não casei por isso e outras coisas também. (Ana)

Os relatos nos fazem visualizar como era o fluxo de amizades e o envolvimento nos espaços sociais: "gostava de passear". Outra dimensão que chama atenção são as questões amorosas: "namorava quando era nova" e "cheguei bem pertinho de casar". 
Para Heilborn (1991), a vida sexual, na rede social, permite que cada sujeito estabeleça uma relação consigo mesmo e com o mundo, garantindo uma dimensão de construção dinâmica, flexível e contextualizada no tempo e no espaço-histórico em que vive.

\section{"Disseram que eu tinha problema de cabeça..."}

Nesta categoria, não objetivamos fazer meras críticas ao hospital psiquiátrico, mas dialogar com as vivências dos colaboradores durante as internações, como meio para avaliar o dispositivo hospitalocêntrico, registrando suas características e, quando possível, estabelecer uma analogia com os princípios da Reforma Psiquiátrica.

Para Santos (2000), quando uma pessoa passa a relatar suas lembranças, transmite emoções e vivências que podem e devem ser partilhadas, transformando-as em experiência, para fugirem do esquecimento.

A partir desse momento, começam a surgir falas que apontam o surgimento do sofrimento psíquico.

... Eu andava nu e tinha medo de gente, tipo indio. O povo chamava: "lá vai o índio, lá vai o indio". Como eu andava nu, a minha mãe procurou o promotor e me trouxe para o hospital. Minha primeira vez não me levaram de novinho, não. Levaram com 15 anos, eu era assim: "desse tamanho, nu", vivendo no mato. Aí, juntou quatro policial, pegaram, algemaram eu e me levaram para o hospital. (Voni)

Eu adoeci foi por causa desse casamento, antes de marcar esse casamento eu tive raiva de uma bahiana, porque ela me escreveu dizendo que ia ter um filho dele. Aí, eu endoideci, fiquei doidinha na hora. Me disseram que era esquizofrenia simples. Eu ficava normal e não sei o 
que era que eu fazia. Tive de ficar internada por que eu tinha crises, dava a crise constantemente, e fui internada várias vezes, mais de 20 vezes, nos dois hospitais daqui [Campina Grande]. Eu nem sei dizer como eram as crises, quem sabia era papai e minha irmã, ela também era doente, a mesma doença dela é a minha. (Ana)

Eu andava demais, por tudo que era canto, eu batia Campina Grande todinha a pés, eu andava de mais! Eu morava com a finada minha mãe e ela dava conselho para eu parar em casa. Eu descobri sobre minha saúde depois de velho, com 30 anos, disseram que eu tinha problema na cabeça. Começou o seguinte: "uma crise que deu em mim, ai eu fiquei sofrendo da cabeça". Uma raiva que eu tive, mas eu não me lembro não. (José)

O adoecimento mental surge em várias facetas nas narrativas, pois culturalmente existem aspectos comportamentais que destoam como sendo da doença mental, cuja compreensão é o desvio das normas sociais, quebra dos padrões vigentes do comportamento sociável: "eu andava nu e tinha medo de gente"; "adoeci foi por causa desse casamento"; "eu andava demais". Andar sem roupa, isolar-se, andar sem destino são fatos que permeiam o imaginário social, relacionando as pessoas que apresentam tais comportamentos como "loucas", apontando o adoecimento mental como caso a ser isolado, por meio da polícia e da internação psiquiátrica. Para as mulheres sem companheiros, relaciona-se a "loucura" com a falta de sexo.

Além disso, tem-se a figura de estranhamento - "lá vai o índio" - fato que tem correlação com o termo alienado, ou seja, alguém que não faz parte do meio, como Amarante (2007) define: é alguém "de fora", estrangeiro, alienígena, fora da realidade, fora de si, sem o controle de suas próprias vontades e desejos. Fora do mundo, de outro mundo (no mundo da lua). 
Outro tema que surge é que eles não sabiam da "doença mental": "me disseram que era esquizofrenia"; "disseram que eu tinha problema na cabeça”. Interessante notar como os colaboradores não sabem do próprio adoecimento - o que faz nas crises? Quanto tempo dura? Quando fica bom?

Como a cultura é (era?) da internação psiquiátrica para as pessoas em sofrimento psíquico, as narrativas trazem as lembranças dos momentos vividos no hospital psiquiátrico, suas peculiaridades, condições assistenciais e estruturais.

No começo, eu entrei no soro, depois de quinze dias eu me senti tão mau com o remédio, haldol, era babando, tremendo assim, era tremendo igual uma vara verde, depois meu filho ia me visitar de 15 em 15 dias... Tomava as injeção, eu não dormia de jeito nenhum, passava mal lá dentro, era aquela ala, um corredor grande, agora eu vivia só trancada, quando meu fi chegava eu tava azeda, um grude, se não tivesse uma pessoa para banhar a gente, pra dar o que comer, ai: "vai, vai, vai para o chuveiro na marra"... Foi depressão, eu não tomei só esses remédios, não. Tomei diazepam, neuleptil, injeção de diempax, tomei sossega leão. (Jucilene)

Quando eu ficava internado no Hospital, vixe Maria! Lá era ver uma cadeia, comida não prestava, era a mesma comida todo dia, eu lá passei muita fome. O tratamento era selvagem, que nem um bucado de burro tudo bravo. (José)

As narrativas apontam a desassistência ao sujeito em sofrimento psíquico no modelo asilar, trazendo um pouco da realidade vivida no hospital psiquiátrico, apontando características como a medicalização excessiva: “me senti tão mau com o remédio", a característica 
de isolamento e distanciamento do mundo "lá era ver uma cadeia" e o tratamento desumano, com baixa qualidade "o tratamento era selvagem".

Todas essas particularidades são apresentadas por Goffman (2003), em sua análise sobre as instituições totais, marcadas pelo afastamento do interno de seu ambiente familiar e social, pelos maus-tratos e pela domesticação através de uso e abuso de medicações, para que os sujeitos se tornassem passivos frente ao processo de internação.

O caráter "total" das instituições, neste caso o hospital psiquiátrico, é simbolizado pela barreira à relação social com o mundo externo e por proibições à saída que, muitas vezes, (na maioria) estão incluídas no esquema físico - por exemplo, portas fechadas, paredes altas, arames farpados e outras:

...pulei o muro, o muro é alto, é quase da altura de um poste desse, eu procurava um jeito e subia, tinha segurança, ai quando eles via, puxava o cabra pela perna, me pegaram muitas vezes, ai botavam para dentro, eu era medicado, tomava injeção. Vixe Maria! Injeção duia pra caramba. (José)

Os internos eram obrigados a se adequar às regras do hospital, onde os menores segmentos de suas vidas estavam sobre julgamentos e regulamentos constantes por parte da equipe de profissionais, com o intuito de atestar a não autonomia daqueles.

No hospital, lá atrás era aonde a gente ia para as refeição. De manhã era a comida. "Ta na hora", todo mundo dizia: "ta na hora do café, ta na hora do almoço". A gente já sabia, nunca fui empurrada por aquelas meninas mais piores do que a gente, ficava sempre de lado, sabia me sair delas, no banho também. No banho era 
um sofrimento, viu? Ficavam o dia todinho, se era chuva, ficava o dia todinho na chuva; se era sol, ficava o dia todinho no sol. (Jucilene)

De manhazinha de 6 horas, essa hora ia tomar banho todo mundo, uma fila de banheiro, para comer era comida normal, feijão e arroz. Para dormir cada cá tinha uma cama, minha cunhada trazia cigarro, fósforo, só que não ficava comigo, ficava com a equipe, ai quando a eu queria dizia: "eu quero fumar", a equipe vinha, ai acendiam um cigarrinho". (José)

O aspecto central das instituições totais pode ser descrito como a ruptura das barreiras que comumente separam as três esferas da vida - o dormir, o brincar e o trabalhar, em diferentes lugares e com diferentes co-participantes - pois, em primeiro lugar, todos os aspectos da vida são realizados no mesmo local e sob uma única autoridade. Em outra dimensão, cada momento das atividades diárias do sujeito é realizado na companhia imediata de um grupo grande de outras pessoas, todas tratadas da mesma forma e obrigadas a fazer as mesmas coisas em conjunto - não há singularidade. Em terceiro lugar, todas as atividades cotidianas são rigorosamente estabelecidas em horários, toda sequência de atividades é imposta verticalmente, por um sistema de regras formais explícitas que devem ser cumpridas e que são garantidas por um grupo de funcionários (GOFFMAN, 2003), quando algum interno foge as regras, então sofre a punição:

Ai quando iam me dar uma injeção, eu sai correndo, mas me pegaram, deram a injeção e me colocaram lá, eu chorava, gritava tanto, lugar de doido, eu gritava: "me dá um copo de água pelo amor de Deus"! Eu fiquei 12 anos ali! Fui para passar uma semana e não sai mais... mas eu ficava fazendo planos para fugir, eu guardava dinheiro, eles tomavam, tirava, sei 
lá como que era aquilo, não tinha saída, toda noite eles me medicavam, ai sempre tinha a enfermeira. (Zoe)

A perspectiva de quem estava no manicômio era que não sairia mais, estava solitário, ser medicado para não fugir, não ter autonomia em relação a sua vida, não possuir dinheiro, pois este tem o simbolismo de poder, além da necessidade de pedir, importuno ou humildemente, algumas coisas pequenas - "eu quero fumar"; "me dá um copo de água" - fatos que causam, gradativamente, a mortificação do eu.

Contudo, essa realidade não continuou sem enfrentar questionamentos, pois em 1978 começaram a surgir as denúncias da violência dos manicômios, da capitalização da loucura, da preponderância da rede privada de assistência, bem como surgiu, coletivamente, uma crítica à psiquiatria clássica e ao modelo hospitalocêntrico no cuidado aos sofredores psíquicos, dando origem a Reforma Psiquiátrica e com ela o processo de desinstitucionalização dos internos dos hospitais psiquiátricos (SANTOS JÚNIOR, SILVEIRA, 2009).

Tal processo de desinstitucionalização foi vivenciado na pele pelos colaboradores do estudo, pois estavam internos na instituição manicomial quando esta sofreu intervenção do Ministério da Saúde e, como consequência, foi fechada devido às baixas condições para prestar assistência.

Ai o hospital fechou. Foi a queda do Hospital, foi a decadência. Ai, Pai J. [proprietário do hospital] disse assim: "olhe, vai fechar o hospital, eu não tenho condição de pagar a prefeitura, tá muito caro o custo de vida aqui, aí vão abrir um hospital que é uma... alugar um prédio"... Mas a minha vida foi lá no Hospital, tomando muito remédio, chamavam de coquetel, eram 6 a 8 drágeas por dia, era só remédio de manhã, 
de tarde e de noite. Eu acho que se ele ainda fosse aberto eu ainda ia estar lá, porque o doutor nunca ia dar alta a mim por completo, por que ele me queria eu lá dentro do hospital e só visitando a família. (Jucilene)

Mas lá [hospital psiquiátrico] não existe mais não, porque tava funcionando, mas fechou, não foi? E porque fechou? Quer dizer que não volta mais não aquele hospital? Volta não, porque não tem clima não! Disseram assim, quando chegou o derradeiro dia "a cantina vai se fechar, vocês vão sair, vai fechar o hospital". Quando fechou, o dono do hospital arribou [foi embora], não ficou não. Fechou porque no Hospital tava o povo dormindo no chão, outros fazendo coco no chão e coisando... tava maltratando, botando pra dormir em cama na talisca, quando chovia, ai o hospital no inverno era o maior frio do mundo, o frio da chuva, $e$ tinha uns que dormia no quartinho trancado, $o$ isolamento, dormia no chão. Quem dava o banho era os homens, minha irmã levou pra lá 8 bermuda e 10 camisa, quando foi pra lavar, eu que perdi. A doutora disse: "esse hospital aqui de todo jeito vai fechar". Chamou minha mãe de Princesa Isabel [município da Paraíba] dizendo que eu ia voltar para casa, ai eu disse: "eu não vou não". Ali ele perguntou: "você vai ficar aonde?". "Eu vou ficar até fechar, vou pra a unidade". Eu não tive alta de lá não, sai porque fechou. (Voni)

Vale pontuar que os colaboradores têm alguma noção dos motivos que levaram ao fechamento do hospital "fechou porque... tava maltratando", apesar de estar presente nas narrativas a colocação do proprietário do hospital, que se mostrou como injustiçado, 
afirmando que não recebia recursos para manter o funcionamento da instituição. Além disso, o que também é marcante é o fato dos colaboradores falarem com muita naturalidade que não receberam alta do hospital, que só saíram porque fechou, pois nunca iriam receber alta "nunca ia dar alta a mim por completo" - como está implícito na cultura, lugar de "doido" é no hospital.

Porém, após presenciar séculos de isolamento do "louco" e da loucura, o mundo consegue enxergar a ineficiência dos hospitais psiquiátricos, asilos e manicômios no tratamento da doença mental. É a partir desse despertar que se inicia a construção de novas formas de cuidar, com o objetivo de produzir saúde sem se ausentar do contexto social da cidade, ou seja, sendo substitutiva ao modo hegemônico e hospitalocêntrico.

\section{"Minha vida ta boa, boa assim... eu to sadio"}

De acordo com o Ministério da Saúde, após um diagnóstico aprofundado do hospital psiquiátrico do município, foi elaborada a proposta de desinstitucionalização, construída em conjunto com os atores envolvidos no processo de intervenção: a equipe interventora (indicada pelo Ministério da Saúde), os representantes da Secretaria Municipal de Saúde de Campina Grande e da Coordenação Estadual de Saúde Mental da Paraíba (BRASIL, 2007).

Dentre as medidas adotadas, foi elaborado um plano de altas, operadas criteriosamente, que exigiram articulações com famílias e serviços de saúde dos locais de origem dos internos. Em um período inferior a 02 meses, esse plano reduziu o número de "pacientes/leitos" (total de 176) do hospital, permanecendo, apenas, 38 sujeitos que já poderiam ser considerados "moradores", pois lá se encontravam entre 02 e 30 anos. Estes foram transferidos, logo em 
seguida, para o Centro de Referência em Saúde Mental, atualmente Unidade de Emergência Psiquiátrica.

Eu passei 7 meses na unidade [Unidade de Emergência Psiquiátrica], ficava dentro do quarto, merendava lá, tomava o lanche. Minha filha ia me visitar, meu filho ia também, até me tirar de lá, quando passou 7 meses. Mara, assistente social, muito boa, falou com meu filho. Ai foi o tempo que ele ajeitou um quarto para mim, ai foi quando eu fui me estabelecer. (Jucilene)

Chegou o dia de tirar a gente de lá [hospital psiquiátrico], arrumaram duas Kombi e encheram com a gente dentro, já tinha uma casa no Alto Branco [residência terapêutica] que foi morar a Gema e outras lá, eram as melhores, né? Depois, abriram outras casas perto do Hotel do Vale, eu fui olhar, os quartos eram grandes. Eu fui para o hospital de meu irmão 1, que tava alugado pela prefeitura para o pessoal que saiu do Hospital [Unidade de Emergência Psiquiátrica], lá eu jogava baralho, ia na missa rezar, passear na rua. Eu tava bem na época, de repente chega a notícia de sair, e me trouxeram para esse apartamento. (Voni)

Todos os colaboradores desta pesquisa se encontravam internos no hospital psiquiátrico por inúmeros anos, portanto os seus vínculos sociais e familiares estavam fragilizados ou, até mesmo, já haviam sido perdidos. Esse longo período de internação não é uma mera passagem na vida dos internos, pois os privam de seu bem maior que é a liberdade e a possibilidade de viver. 
Visando a uma melhor reintegração na comunidade, os egressos (moradores) do hospital foram encaminhados para a Unidade de Emergência Psiquiátrica - "eu passei 7 meses na unidade" - onde foram trabalhadas as questões iniciais do processo de ressocialização: "lá eu jogava baralho, ia na missa rezar, passear na rua", bem como foi um período de contato com os familiares para promover o retorno do ex-interno para o seio familiar: "minha filha ia me visitar"; ou outro espaço comunitário: "me trouxeram para esse apartamento".

Para os que não foi possível o contato com a família ou que a mesma não mais os aceitava, foram elaborados, paulatinamente, de forma planejada e avaliando-se caso a caso, encaminhamentos para as Residências Terapêuticas, espaço de morar e viver na comunidade. Nesse processo, em cerca de um ano, Campina Grande conseguiu reverter seu modo de atenção à saúde mental, passando do modelo hospitalocêntrico para o modelo de atenção psicossocial.

Eu sai de lá [hospital psiquiátrico] porque fechou, mas graças a Deus estou aqui [Residência Terapêutica], é melhor aqui, aqui é bom. Minha vida só não tem sido boa porque eu sinto umas agonias sabe, todos os dias eu tenho uma complicação, sabe? Todos os dias sabe a mesma coisa, não sei se depois do lanche até não sei que hora, mas não é culpa daqui não, é coisa lá de fora. Eu ouço vozes, eu tenho esse ouvido perdido e eu ouço vozes por aqui, por esse ouvido perdido, elas dizem o que esta acontecendo, esses escândalos que ta acontecendo por ai, eu sei que esta porque a televisão não dá, dá, mas confundindo, né?

É interessante o conteúdo que essa narrativa traz. Inicialmente, compara sua nova moradia com o tempo em que estava no hospital psiquiátrico: "é melhor aqui, aqui é bom"; em segundo lugar, traz 
uma desconstrução cultural sobre a loucura, a qual diz que escutar vozes - fato cientificamente chamado de alucinação auditiva - é sinal de crise. Contudo, a colaboradora relata a alucinação: "eu ouço vozes", como auxílio para entender os eventos que lhe rodeiam diariamente. Porém, não quero dizer que só porque essa colaboradora saiu do hospital e agora habita em uma residência, os sinais psicóticos são diferentes ou menos importantes, o que chamamos a atenção é para o fato de que antes, escutar vozes era um problema, geralmente determinante para a internação, e agora é o que a orienta sobre o mundo exterior.

Goffman (2003) diz que é característico dos internados que cheguem à instituição com uma cultura aparente - uma forma de vida e um conjunto de atividades aceitas sem discussão até o momento de admissão na instituição, porém se a estadia do interno é muito longa, pode ocorrer, caso ele volte para o mundo exterior, o "desculturamento" - que é a incapacidade temporária de enfrentar alguns aspectos de sua vida diária.

Hoje em dia não sei fazer nada, eu não sei lavar um copo que preste, se eu for lavar, minha filha vai e reclama, diz que eu faço mal feito, não faço bem feito. (Jucilene)

Eu não faço nada, nada, nada, só assisto televisão e me deito, não faço porque não consigo, mas tem ai, tem prato para lavar, eu não lavo nem meu prato... Eu vou na psicóloga, não sei a rua da psicóloga, é um consultório, eu só converso porque ela puxa conversa, mas eu não era assim não, fiquei depois [da internação psiquiátrica], eu gostava de conversar, mas agora não sei conversar com ninguém. (Ana)

Porém, esse fato não inviabilizou o resgate das questões de vida cotidiana mais elementar, que foram desconstruídas atrás 
dos muros manicomiais. Tal perspectiva estimula a autoestima, o atendimento das necessidades diárias, minimizando as limitações, potencializando os hábitos saudáveis e viabilizando a autonomia para a vida na comunidade. Pois, a realização das atividades do dia a dia deve ser tomada como um dos primeiros objetivos a serem alcançados nos projetos de reabilitação psicossocial (SOARES, SAEKI, 2006).

Elas pedem dinheiro a gente e eu compro alguma coisa, eu to comprando agora iogurte, porque meu intestino é meio parado, sabe? $\mathrm{E}$ eu não queria tomar remédio para isso... eu recebo dinheiro aqui, 20 reais por semana, as meninas quando falta tempero aqui não é remédio, né? Acho que isso não influi não, né? Eu vou para a psicóloga terça e quinta e pro CAPS eu ia segunda e... esqueci, não to indo mais, por que eu agora vou para uma psicóloga. (Ana)

Minha vida ta boa, aqui [residência terapêutica] eu alimpo a mesa, varro o chão. Eu vou no mercadinho e sei vim, chego lá digo assim: "vim aqui comprar coca-cola", levo 4 reais, que dá para comprar um refrigerante, cada um dá uma pratinha daquela de 0,50 centavo. A gente se damo bem, é sete pessoa aqui, eu tenho minha caminha. Minha saúde ta boa, boa assim...eu to sadio. To sadio é assim, to com saúde [risadas]. (Voni)

Emergem nas falas algumas das atividades cotidianas já realizadas: "eu alimpo a mesa, varro o chão"; a circulação do meio social, apontando para autonomia de vida: "vou no mercadinho e sei vim", porém, percebe-se que o passaporte para essa tão falada autonomia é o poder de aquisição de bens e consumos: "recebo dinheiro"; "levo 4 reais, que dá para comprar um refrigerante", representado, neste 
caso, pelo dinheiro que recebem do Programa de Volta para Casa (PVC), fomentado pelo Ministério da Saúde. Tal programa objetiva estimular o retorno dos egressos de longas internações psiquiátricas para sua família, bem como serve de apoio social, pois sabe-se das dificuldades de uma pessoa com sofrimento psíquico entrar para o mercado de trabalho e se tornar financeiramente ativa.

Essa questão do PVC é narrada a seguir:

Quando eu saí da unidade, eu fui para o CAPS, ai Mara e um monte de gente que tinha lá, vieram fazer meu acolhimento. Disseram que eu não precisava ir para a residência e que iam fazer um documento que vinha de Brasília para eu receber 240 reais [Programa de Volta Para Casa], dinheiro que eu pago aluguel e meu filho complementa. Muita gente recebe. Geraldo tem. A maioria que tava no Hospital recebe esse dinheiro.

Para quem eram condenados pela incapacidade de se relacionar, pela impossibilidade de conviver nos espaços sociais, sendo considerados irresponsáveis civis, as narrativas trazem outra realidade, pois os colaboradores sabem fazer contas: "dinheiro que eu pago aluguel"; decidem o que comprar: "levo 4 reais, que dá para comprar um refrigerante", o que demonstra a capacidade de viver em sociedade, além de se sentirem bem, saudáveis: "minha saúde tá boa, boa assim...eu to sadio"

A assistência ao sofredor psíquico pela lógica da Reforma Psiquiátrica tem proporcionado uma maior autonomia dos sujeitos, viabilizando uma maior circulação nos espaços cotidianos da comunidade. Configurando os serviços substitutivos como mais espaços de circulação social, de lazer e de contato com outras pessoas, como o Centro de Apoio Psicossocial (CAPS) (SANTOS JÚNIOR; SILVEIRA, 2009): 
Bom, agora eu fico participando no CAPS, a minha oficina é fuxico, que eu nem gosto, é saúde e cidadania, leitura, dança de Dr Pedro advogado. Ai, eu fico fazendo essas oficinas, só não vou para a do crochê, porque não entendo nada, não sei nem para aonde vai, meus dias são segunda, quarta e quinta-feira. Tem a piscina, mas eu não vou não, eu já fui tomar banho na piscina, mas me fizeram tanto medo dizendo que um pessoal morreu nela que eu não fui. (Jucilene)

Lá no CAPS eu participo de palestra, é fazendo desenho, fazendo coisa lá... desenho, artesanato. Eu vou no ônibus sozinho, eu ia com meu irmão, mas hoje eu sei, é o ônibus 555 e para voltar eu apanho o ônibus 505 na frente da rodoviária. Tem um bucado de doida lá, mas eu não quero nenhuma não, é tudo feia. Ah, uma galega daquelas que trabalha lá dava pra viver. Hoje minha vida ta muito boa graças a Deus, primeiramente Deus, depois ela [cunhada], porque agora eu to no céu e de primeira eu não tava não. Eu gosto daqui, eu quero assistir televisão tenho, quero comer tenho tudo, não falta nada, tudo é fartura pra mim aqui, eles me tratam que nem que seja um filho deles. Minha saúde ta boa hoje, para a vista que era ta boa, porque eu não tive mais crise, não da mais vontade de andar como eu andava. Meu tratamento é tomar o remédio e ir de $15 \mathrm{em}$ 15 dias na médica. Eu não faço nada, só faço dar caminhada pelo Zé Pinheiro [bairro onde mora], comer e dormir. Vou na casa de uma amiga, tomo um café converso... tomo a medicação sozinho sem derrubar, antes tinha que dar na boca. (José) 
Devido à prática de segregação e exclusão do sofredor psíquico, todas as atividades realizadas devem ter como objetivo central promover a reinserção social: "eu fico participando no CAPS"; proporcionando-lhes autonomia: "eu vou no ônibus sozinho"; através do processo de reabilitação psicossocial, com reaprendizagem de atividades cotidianas e sociais necessárias para a vida em comunidade. Para tal, são tomadas como recursos de alto valor terapêutico as formas universais de lidar com problemas como a amizade: "vou na casa de uma amiga"; a religião e o entretenimento: "só faço dar caminhada". Percebe-se que se trata de reinventar a vida em seus aspectos mais comuns, pois é principalmente do cotidiano da cidade que se encontram privados os sofredores psíquicos.

\section{Então, as histórias foram rememoradas...}

Foi com o olhar sobre o processo saúde-doença mental, na perspectiva antropológica e etnográfica, que partimos para executar este estudo, e foi com ele que chegamos às considerações ora apresentadas, acerca dos resultados encontrados.

Esta pesquisa etnográfica possibilita o conhecimento a respeito da atenção à saúde mental, pois os colaboradores que vivenciaram o tratamento hospitalar e hoje estão inseridos nos serviços extra-hospitalares, narram suas trajetórias individuais, eventos e processos que, muitas vezes, foram o que culminou no seu adoecimento e na determinação de sua "carreira" como "doente mental", portanto, passível do poder psiquiátrico. Além de que possibilitou retirar das sombras e dar voz ao segmento social da "doença mental", que embora faça parte da História, esteve (ou ainda está) dela marginalizado por muito tempo.

Há que se frisar que as estórias de vida apresentam uma grande quantidade de dados primários, os quais permitem, além de descrições precisas da situação estudada, ilustrar a perspectiva dos 
colaboradores, isto é, as suas maneiras de ver o mundo e suas próprias ações e consequências.

Por isso, pois, refletimos que quando se propõe o fim dos manicômios, não é apenas a "derrubada" de um prédio ou dos seus muros, mas sim na forma como lidamos com as pessoas em desvantagens sociais, que não permite a diferença, afinal, ninguém escolhe ficar "louco"!

\section{Referências}

AMARANTE, P. Saúde mental e atenção psicossocial. Rio de Janeiro: Fiocruz, 2007.

BRASIL. Ministério da Saúde. Secretaria de Atenção à Saúde/DAPE. Saúde mental no SUS: acesso ao tratamento e mudança no modelo de atenção. Relatório de Gestão 2003-2006. Brasília: Ministério da Saúde, 2007.

GEERTZ, C. A. Interpretação das culturas. Rio de Janeiro: Livros Técnicos e Científicos, 1989.

GOFFMAN, E. Manicômios, prisões e conventos. $7^{\circ}$ ed. São Paulo: Perspectiva, 2003.

GUALDA, D. M. R.; BERGAMASCO, R. B. Processo saúde-doença: evolução de um conceito. In: GUALDA, D. M. R.; BERGAMASCO, R. B. (Orgs). Enfermagem, cultura e o processo saúde-doença. São Paulo: Ícone, 2004. p. 25-37.

GUALDA, D. M. R. Eu conheço minha natureza: a expressão cultural do parto. Curitiba: Maio, 2002. 
HEILBORN, M. L. Gênero e condição feminina: uma abordagem antropológica. In: INSTITUTO BRASILEIRO DE ADMINISTRAÇÃO MUNICIPAL. Mulher e políticas públicas. Rio de Janeiro, 1991.

MINAYO, M. C. S. O desafio do conhecimento: pesquisa qualitativa em saúde. 6 Ed. São Paulo: Hucitec, 1999.

SANTOS, A. C. A. Fontes orais: testemunhos, trajetórias de vida e história. Departamento de História Universidade Federal do Pará. Revista Via Atlântica, v. 4, p. 1-10, 2000.

SANTOS JÚNIOR, H. P. O.; SILVEIRA, M. F. A. Práticas de cuidados produzidas no serviço de residências terapêuticas: percorrendo os trilhos de retorno à sociedade. Rev esc enferm USP, v. 43, n. 4, p. 788-795, 2009.

SOARES, S. R. R.; SAEKI, T. O centro de atenção psicossocial sob a ótica dos usuários. Rev Latino-am Enferm, v. 14, n. 6, p. 105-112, 2006. 